\title{
SEDIMENT DEPOSITION IN A SOUTH SULAWESI SEAGRASS BED
}

\author{
Mahatma Lanuru ${ }^{1, *}$ and Ramdina Fitri ${ }^{2}$ \\ ${ }^{1}$ Department of Marine Science, Hasanuddin University, Makassar \\ ${ }^{2}$ Department of Marine Science, Indonesian Moslem University, Makassar \\ *e-mail:mahat70@gmail.com
}

\begin{abstract}
Deposition of suspended sediment was measured with sediment traps in shallow coastal waters colonized by Thallasia dominated seagrass in Pannikiang Island, South Sulawesi (Indonesia). The primary objective of this study was to compare the amounts of sediment deposition inside seagrass beds and in adjacent unvegetated area. The traps were placed in a seagrass bed (Station I, II, and III) and in an adjacent unvegetated area (Station IV) measuring the sediment flux on the seabed. The sediment fluxes due to deposition were significantly higher at stations I and II $(\mathrm{P}<0.05)$ and station III $(\mathrm{P}<0.01)$ than at station IV (unvegetated area). Results of this study suggest that sediment deposition was promoted by dense shoots of seagrass. The study provides quantitative evidence for the importance of seagrass bed as sites of sedimentation of fine particles.
\end{abstract}

Keywords: Sediment, deposition, sediment trap, seagrass, South Sulawesi, Indonesia

\section{INTRODUCTION}

Seagrass beds are higly productive and dynamic ecosystems. They are found in coastal area that are subjected to varied tidal fluctuations, influx of freshwater and eutrophication. Beds provide an important habitat for many marine organisms including juvenile fish and macroinvertebrate species, providing a place for shelter and refuge. They also provide valuable food source for grazing aquatic invertebrates that feed on the epiphytes living on the seagrass (Fairhurst and Graham, 2003).

Seagrass beds are also known to promote deposition of particles (Almasi et al., 1987), and loss of seagrass beds is often followed by sediment erosion (Christiansen et al., 1981). This effect of seagrass beds on sediment deposition results from the reduction of water flow (Fonseca et al., 1982), and the protection of sediments against the resuspension due to energy dissipation by the plant canopies (Ward et al., 1984).

The influence of seagrass bed on the process of hydrodynamics and sedimentation has been an interesting topic in recent years. However, there was relatively few research in Indonesia regarding this field. Previous seagrass studies in Indonesia mostly deal with biological and ecological of seagrasses (e.g. Erftermeijer et al., 1993; Sterrenburg et al., 1995) rather than physical (hydrodynamics) and sediment dynamic in seagrass bed. This paper, thus, evaluates the influence of seagrass on the process of sedimentation. The primary objective of this study was to compare the amounts of sediment deposition inside seagrass beds and in adjacent unvegetated area.

\section{MATERIALS AND METHODS}

The field work was conducted in June 2005 at shallow coastal waters colonized by Thallasia dominated seagrass in Pannikiang Island, South Sulawesi (Fig.1). Four sampling stations were worked out in the study area consisted of three stations in a seagrass bed and one station in an adjacent unvegetated area. These three seagrass stations were each located at south side (Station I), north side (Station II), and west side (Station III) of the island, while the station of unvegetated area was located at east side of the island (Station IV). 


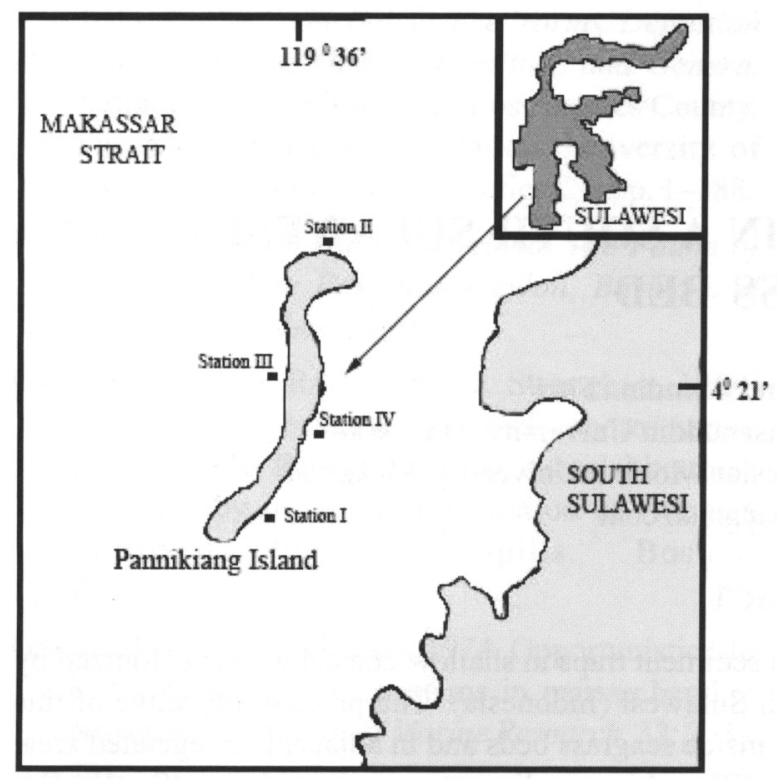

Figure 1. Map of study site.

Three sediment traps were deployed at the sea-bed at each sampling station to measure the amounts of sediment deposition. The traps consist of PVC tubes closed at the lower end. The inner diameter of the tubes is $3.0 \mathrm{~cm}$ and the length of the tube is $15.0 \mathrm{~cm}$ giving an aspect ratio of 5 which is consider optimal for measuring sediment flux in horizontal flows, in which maximum speed infrequently reach $0.2 \mathrm{~m} \mathrm{~s}^{-1}$ (Gardner, 1980). All traps were mounted on an iron stick of $50 \mathrm{~cm}$ long, diameter $0.5 \mathrm{~cm}$, and driven into the sea bottom at each sampling station.

Sediment deposited at the traps was collected after a 3 days deployment period to measure the gross sediment flux, defined as the amount of sediment that comprises both a net sediment flux and a sediment flux induced by resuspension (Lund-Hansen and Eriksen, 1996). The net sediment flux is defined as the amount of sediment that is permanently deposited at a site. Materials collected in the traps were filtered using preweighed Millipore GEM filter of $0.45 \mu \mathrm{m}$ pore size. The filters were dried for 2 hours at $105^{\circ} \mathrm{C}$ and weighed.

At a seagrass bed a quadrant of $1 \mathrm{~m}^{2}$ metal pipe frame was laid, and the number of seagrass shoots were counted. This quadrant is divided into 16 subdivisions to facilitate calculation. Samplings were done randomly in order to avoid overestimation (Dennison, 1990).

One-way ANOVA was used to test difference in deposition rate between stations. Differences were regarded as statistically significant when the probability of error was lower than $5 \%(\mathrm{P}<0.05)$. Tukey's multiple comparison test was used to locate any differences identified by ANOVA (Fowler and Cohen, 1997).

\section{RESULTS}

The mean deposition rate within the seagrass bed varied from minimum values of 7.3 at station I to maximum values of $16.6 \mathrm{~g} \mathrm{~m}^{-2} \mathrm{~d}^{-1}$ at station III. The mean deposition rate at Station IV varied from minimum values of 0.9 to maximum value of $5.9 \mathrm{~g} \mathrm{~m}^{-2} \mathrm{~d}^{-1}$ (Fig. 2). ANOVA analysis revealed that sediment fluxes due to deposition were significantly higher at stations I and II $(\mathrm{P}<0.05)$ and station III $(\mathrm{P}<0.01)$ than at station IV. However, there were no significant differences in sediment fluxes due to deposition detected between seagrass stations. These results indicated that deposition rates were significantly higher at seagrass bed than those at adjacent unvegetated area.

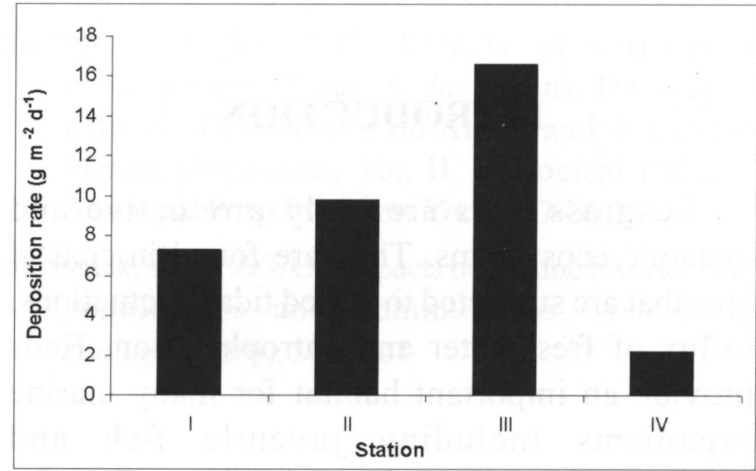

Figure 2. Deposition rate at the seagrass bed (stations I, II, and III) and unvegetated area (station IV).

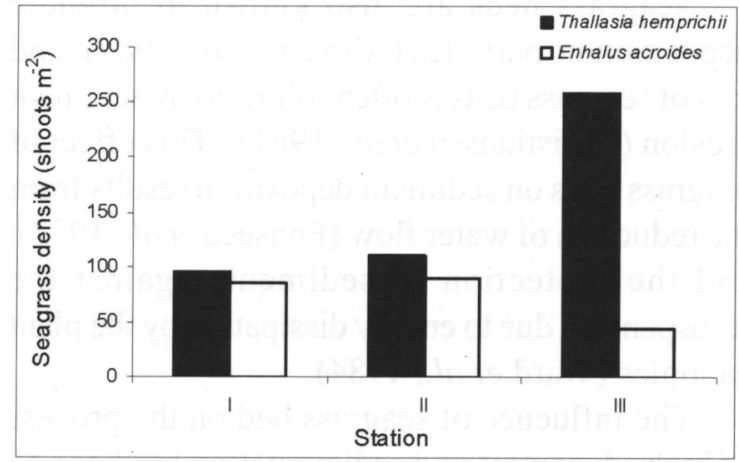

Figure 3. Shoots density of Thallasia hemprichii and Enhalus acroides at the study site. 
The mean shoot density of Thalassia hemprichii at the study site varied from minimum value of 96 at Station I to maximum value of 258 shoots $\mathrm{m}^{-2}$ at Station III. The density of Enhalus acoroides at the study site was lower than Thalassia hemprichii which varied from minimum value of 44 at Station III to maximum value of 90 shoots $\mathrm{m}^{-2}$ at station II (Fig. 3).

\section{DISCUSSION}

The deposition rates recorded for the present study are lower than those reported from around the world (Table 1). The values observed in the South Sulawesi are low when compared to the rates reported for shallow coastal area in The Philippines and Hong Kong, East China Sea (Table 1). This comparison should, however, be considered with caution, since our data only reflect a single short-term sampling duration. Furthermore, as we did not sample under extreme weather conditions that may enhance deposition (e.g. heavy rainfall and typhoons) the range of values reported here should represent the minimum estimates of the average deposition rate in the area.

Deposition rates were significantly higher in the seageass bed than in the adjacent unvegetated area suggesting that deposition of fine particles is promoted by dense shoots of seagrass. These results agree with other studies, e.g. by Almasi et al. (1987) who found that sedimentation rates were higher inside seagrass area than unvegetated area.

Higher deposition rates found in the seagrass bed area probably due to the ability of the seagrass to slow down current velocity (Fonseca et al., 1982 ) and due to wave orbital velocity near the bottom (Ward et al., 1984) creating a quiescent environment which is favorable for suspended particles to settle out from the water column. In addition, leaves together with epiphytic growth on the leaves of the seagrass can actively trap finer-grained sediments transported over the seagrass by adhering waterborne particles to the leaves.

Efficacy of seagrass in trapping suspended particles depends on several factors such as shoot density, type and size of seagrass. The deposition rate tends to increase with increase of Thalassia hemprichii density in this study. As an example, deposition rate was high at Station III where the shoot density of Thalassia hemprichii was also high. This result is similar with the results of Ukkas et al. (2000) who found that the increase of sedimentation rate was parallel with the increase of density of artificial seagrass shoots. Unlike Thalassia hemprichii, the trend of increasing deposition rate with increasing shoot density was not observed for Enhalus acoroides. This fact indicates that at the study site Enhalus acoroides was less effective in enhancing sediment deposition than Thalassia hemprichii.

\section{CONCLUSION}

The deposition rates were significantly higher at seagrass bed than those at adjacent unvegetated area suggesting that deposition of fine particles is promoted by dense shoots of seagrass. Higher deposition rates at seagrass bed than those at

Table 1. Range and mean sediment deposition rate for different shallow coastal area.

\begin{tabular}{|c|c|c|c|c|c|}
\hline \multirow[t]{2}{*}{ Locality } & \multicolumn{2}{|c|}{$\begin{array}{l}\text { Deposition rate } \\
\left(\mathrm{g} \mathrm{m}^{-2} \mathrm{~d}^{-1}\right)\end{array}$} & \multirow{2}{*}{$\begin{array}{l}\text { Deployment } \\
\text { depth }(m)\end{array}$} & \multirow[t]{2}{*}{ Area/bottom } & \multirow{2}{*}{ Reference } \\
\hline & Range & Mean & & & \\
\hline $\begin{array}{l}\text { Bay of Calvi, Corsica } \\
\text { (Mediterranean) }\end{array}$ & $0.04-9.8$ & 2.3 & 36 & $\begin{array}{l}\text { Posidonia } \\
\text { oceanica }\end{array}$ & $\begin{array}{l}\text { Dauby et al. } \\
\text { (1995) }\end{array}$ \\
\hline $\begin{array}{l}\text { Chesepeake Bay (N.W. } \\
\text { Atlantic) }\end{array}$ & $23-115$ & 51.4 & $<1$ & Rupia maritima & $\begin{array}{l}\text { Ward et al. } \\
\text { (1984) }\end{array}$ \\
\hline $\begin{array}{l}\text { Kiel Bight } \\
\text { (Baltic sea) }\end{array}$ & $0.1-79.9$ & 4.6 & 18 & mud & $\begin{array}{l}\text { Smetacek } \\
\text { (1980) }\end{array}$ \\
\hline $\begin{array}{l}\text { Philippines } \\
\text { (S. China Sea) }\end{array}$ & $18-175$ & - & $<3$ & mixed seagrass & $\begin{array}{l}\text { Gacia et al. } \\
(2003)\end{array}$ \\
\hline $\begin{array}{l}\text { Hong Kong } \\
\text { (S. China Sea) }\end{array}$ & $29-145$ & 67.4 & 1.4 & Zostera japonica & Lee (1997) \\
\hline $\begin{array}{l}\text { South Sulawesi, } \\
\text { Indonesia (Makassar } \\
\text { strait) }\end{array}$ & $0.9-16.6$ & 8.3 & $<1$ & mixed seagrass & This study \\
\hline
\end{tabular}


adjacent unvegetated area are probably due to baffling (slowing down current and wave orbital velocity near the bottom) and trapping effects of the seagrass shoots. The present study provides quantitative evidence for the importance of seagrass bed as sites of sedimentation of fine particles.

Acknowledgements. This work was made possible through financial support provided by Ramdina Fitri as part of her bachelor work. The authors thank Isyanita for laboratory works.

\section{REFERENCES}

Almasi, M.N., C. Hoskin, M. Reed, and J. Milo. 1987. Effects of natural and artificial Thalassia on rates of sedimentation. Journal of Sedimentary Petrology, 57(5): 901-906.

Christiansen, C., H. Christoffersen, J. Dalsgaard, and P. Nørnberg. 1981. Coastal and nearshore changes correlated with die-back in ell-grass (Zostera marina, L.). Journal Sedimentary Geology, 28: 163-173.

Dauby, P., A.J. Bale, N. Bloomer, C. Canon, R.D. Ling, A. Norro, J.E. Robertson, A. Simon, J.M. Theate, A.J. Watson, and M. Frankiegnoulle. 1995. Particle flux over a Mediterranean seagrass bed: a one year case study. Marine Ecology Progress Series, 126 : 233-246.

Dennison, W.C. 1990. Shoot density. In: R.C. Philips and C.P. Mc Roy (editors), Seagrass research methods. UNESCO, Paris. p.61-63.

Erftemeijer, P.L.A., R. Osinga, and A.E. Mars. 1993. Primary production of seagrass beds in South Sulawesi (Indonesia): a comparison of habitats, method and species. Aquatic Botany, 46: 67-90.

Fairhurst, R.A. and K.A. Graham. 2003. Seagrass bed-sediment characteristics of Manly Lagoon. In: Freshwater Ecology Report 2003. Department of
Environmental Sciences, University of Technology, Sydney.

Fowler, J., and L. Cohen. 1997. Practical statistics for field biology (227 pp.). Chichester: Wiley.

Fonseca, M.S., J.S. Fisher, J.C. Zieman, and G.W. Thayer. 1982. Influence of seagrass, Zostera marina, on current flow. Estuarine Coastal Shelf Science, 15: 351-364.

Gacia, E., C.M. Duarte, N. Marba, J. Terrados, H. Kennedy, M.D. Fortes, and N.H. Tri. 2003. Sediment deposition and production in SE-Asia seagrass meadows. Estuarine, Coastal and Shelf Science, 56: 909-919.

Gardner, W.D. 1980. Field assesment of sediment traps. Journal of Marine Research, 38: 41-52.

Lee, S.Y. 1997. Annual cycle of biomass of a threatened population of the intertidal seagrass Zostera japonica in Hong Kong. Marine Biology, 129: 183 193.

Lund-Hansen, L.C., and A.T. Eriksen. 1996. Sediment fluxes, surface wave induced resuspension process, and effects in a shallow water embayment. Recent Res. in coastal Res., 1: 53-70.

Smetacek, V. 1980. Annual cycle of sedimentation in relation to plankton ecology in Western Kiel Bigh. Ophelia, 1: 65-76.

Sterrenburg, F.A.S., P.L.A. Erftemeijer, and P.H Nienhuis. 1995. Diatoms as epiphytes on seagrasses in South Sulawesi (Indonesia) comparison with growth on inert substrata. Botanica Marina, 38: 1-7.

Ukkas, M., A.R. Jalil, A. Tuwo, and Mursalim. 2000. The effect of artificial seagrass density to sedimentation in the waters of Barrang Lompo island. Torani, 10: 24-29.

Ward, L.G., W.R. Boynton, and W.M. Kemp. 1984. The influence of waves and seagrass communities on suspended particulates in an estuarine embayment. Marine Geology, 59: 85-103. 